\title{
ANALISIS PRODUK ASURANSI UNIT LINK DI INDONESIA
}

\author{
I Nyoman Widana $^{1 \S}$, Ketut Jayanegara ${ }^{2}$ \\ ${ }^{1}$ Program Studi Matematika, Fakultas MIPA - Universitas Udayana [Email: nwidana@yahoo.com] \\ ${ }^{2}$ Program Studi Matematika, Fakultas MIPA - Universitas Udayana [Email: ktjayanegara@unud.ac.id] \\ ${ }^{\S}$ Corresponding Author
}

\begin{abstract}
This paper presents a unit-linked insurance which is a modern insurance. The policyholders will get benefits of insurances and investment. The aim of this research is to analysis of unit link insurance products in Indonesia. Especially to analysis the mortality cost, premium, return, and profit of the product. The method used is a stochastic profit testing method and the results of the study show that mortality cost offered by the three unit link companies selected as the sample of this study are greater than the insurance costs calculated based on the Indonesian Mortality Table. From comparing different unit linked insurance plans, only one plan is sufficient to fund the guarantee. While others have to do a Top-up premium.
\end{abstract}

Keywords: Mortality Cost, Proftit Testing, Premium

\section{PENDAHULUAN}

Asuransi didesain untuk mengatasi masalah-masalah finansial yang ditimbulkan dari kejadian-kejadian yang tidak terduga, seperti kematian, sakit, kebakaran atau kehilangan. Ini berarti asuransi memiliki peran yang vital dalam kehidupan sehari-hari karena dapat meringankan beban hidup seperti menanggung biaya pengobatan jika sakit, biaya perbaikan rumah jika terbakar dan lain-lainnya. (Bowers et al 1997). Berdasarkan periodenya, ada dua jenis asuransi yaitu asuransi tradisional dan asuransi modern. Contoh produk asuransi tradisional adalah asuransi berjangka (term insurance), asuransi jiwa seumur hidup (whole life insurance), dan asuransi dwiguna (endowment insurance). Sedangkan contoh produk asuransi modern adalah unit link yang mengaitkan (link) antara investasi dan asuransi. Perlu diperhatikan bahwa produk asuransi tradisional hanya menawarkan proteksi saja, sedangkan produk asuransi modern selain menawarkan proteksi juga menawarkan investasi. .

Saat ini asuransi unit link yang dikemas secara modern berkembang dengan sangat pesat di Indonesia. Produk unit link ini mulai dipasarkan oleh 3 perusahan asuransi di tahun 1997. Saat ini ada lebih dari 41 perusahan yang menawarkan produk unit link. Pesatnya perkembangan ini tentu berkaitan dengan manfaat return dari investasi dan perlindungan dari asuransi yang diperoleh oleh nasabah unit link. Meskipun tumbuh secara pesat, namun sebagian masyarakat belum memahami secara tepat mengenai manfaat dan risiko dari produk unit link ini.

Mandal (2016) telah membahas unit link di India dengan menggunakan beberapa parameter untuk membandingkan produk-produknya. Selain itu dalam penelitiannya yang berjudul "Unit Linked Insurance Palans and Their Applications in India" diuraikan juga pendekatan deterministik dan stokastik untuk menghitung profit testing dari produk unit link. Selain itu, Soedibjo dan Fitriati (2009) juga telah menggunakan pendekatan profit testing dalam menghitung penetapan target premi asuransi jiwa syariah untuk mencapai titik impas. Dalam penelitiannya juga dibahas mengenai premi, kinerja investasi dan biaya.

Faktor yang mempengaruhi harga premi dari produk unit link ini antara lain adalah 
tingkat angka kematian (tabel mortalita) dan biaya. Ada beberpa komponen biaya, selain biaya asuransi, yang harus dibayarkan oleh nasabah produk unit link. Biaya tersebut antara lain meliputi biaya administrasi, biaya alokasi premi dan biaya pengelolaan investasi. Besarnya biaya unit link ini sangat bergantung dari kebijakan masing-masing perusahan asuransi. Demikian juga dengan return yang akan diperoleh oleh nasabah unit link sangat bervariasi antara satu perusahan asuransi dengan perusahan asuransi yang lainnya. Selain itu, produk ini tidak bebas dari resiko yang harus ditanggung oleh pemilik polis itu sendiri. Sehingga masyarakat harus hati-hati dalam membeli produk ini. Berdasarkan uraian tersebut, penelitian ini akan menganalisis produk unit link dari beberapa perusahan asuransi di Indonesia

\section{METODE PENELITIAN}

\section{Jenis dan Sumber Data}

Penelitian ini memanfaatkan data sekunder yang bersumber dari tiga perusahan asuransi unit link yang ada di Indonesia. Adapun datanya antara lain meliputi, biaya asuransi, biaya akuisisi, biaya pengelolaan dana, biaya admininistrasi, uang pertanggungan, masa pertanggungan, biaya, besar premi, umur peserta data historis dari return, dan lain-lainnya.

\section{Metode Analisis Data}

Analisis aliran kas (cash flow analysis) dapat dilakukan dengan pendekatan deterministik dan pendekatan stokastik. Pendekatan yang pertama menggunakan asumsi tingkat suku bunga konstan (baca: return konstan). Sedangkan pendekatan stochastic mengasumsikan retunnya merupakan suatu varibel random yang mempunyai distribusi lognormal. (Dickson et al, 2009)

Definisi 1. Misalkan $T(x)$ adalah varibel random kontinu yang menyatakan sisa usia (future lifetime) dari orang yang berusia $x$ tahun.

Notasi ${ }_{t} q_{x}$ menyatakan peluang orang yang berusia $x$ tahun tidak akan hidup melampaui usia $x+t$ tahun. Fungsi distribusi dari $T(x)$ adalah

$$
{ }_{t} q_{x}=P(T(x) \leq t)
$$

Definisi 2. Misalkan ${ }_{t} p_{x}$ menyatakan peluang orang yang berusia $x$ tahun akan mencapai usia $x+t$ tahun.

$$
{ }_{t} p_{x}=P(T(x)>t)=1-{ }_{t} q_{x}
$$

Ekpektasi manfaat kematian (expected death benefit) untuk orang yang berusia $x$ tahun dengan benefit sebesar $B_{t}$, pada saat $t$ dinyatakan dengan

$$
E D B_{t}=B_{t} q_{x+t-1}
$$

Definisi 3. $F_{t}$ menyatakan jumlah uang yang disimpan di rekening pemegang polis (policy holder's account) pada saat $t$.

Definisi 4. $P_{t}$ menyatakan jumlah uang yang dibayarkan oleh pemegang polis ke pihak penanggung (insurer)

Definisi 5. $A P_{t}$ bagian dari $P_{t}$ yang diinvestasikan.

Projeksi dari dana pemegang polis dirumuskan sebagai berikut

$$
F_{t}=\left(A P_{t}+F_{t-1}\right)\left(1+i_{t}^{f}\right)-M C_{t}
$$

dengan

$i_{t}^{f}$ menyatakan tingkat bunga yg diperoleh oleh pemegang polis pada saat $t$.

$M C_{t}$ menyatakan biaya manajemen pada saat $t$.

Profit emerging pada saat $t$ dirumuskan sebagai,

$$
P r_{t}=U A P_{t}+I_{t}-E_{t}+M C_{t}-E D B_{t}
$$
dengan

$U A P_{t}$ menyatakan premi yang tidak dialokasikan untuk investasi.

$E_{t}$ menyatakan expenses pada saaat $t$.

Sedangkan ekspektasi nilai tunai dari keuntungan atau dikenal dengan istilah net present value (NPV) dinyatakan oleh hubungan berikut

dengan

$$
N P V=\sum_{t=0}^{n} \Pi_{\mathrm{t}} \mathrm{v}_{\mathrm{r}}^{\mathrm{t}}
$$

$v_{r}^{t}=\left(1+i_{r}^{t}\right)$ dan $i_{r}^{t}$ menyatakan tingkat bunga untuk perusahan pada saat $t$.

$\Pi_{\mathrm{t}}={ }_{t-1} p_{x} \operatorname{Pr}_{t}$

Asumsi yang digunakan pada penelitian ini adalah returnnya mempunya distribusi lognormal. Atau dengan kata lain 
$\log R_{t} \sim N\left(\mu_{t}, \sigma_{t}^{2}\right)$. Perlu dicatat bahwa $R_{t}-1$ merupakan tingkat bunga yang diperoleh pada saat $t$. Selanjutnya, misalkan $m$ dan $s$ berturutturut menyatakan mean dan standar deviasi dari NPV. Maka dengan menggunakan teorema limit pusat diperoleh (Dickson et al, 2009)

$$
E[N P V]=\left(m-1.96 \frac{s}{\sqrt{N}}, m+1.96 \frac{s}{\sqrt{N}}\right) .
$$

dengan tingkat kepercayaan $95 \%$ dan $N$ menyatakan jumlah simulasi yang dilakukan.

Adapun tahap-tahap analis data dalam penelitian ini sebagai berikut:

1. Mengumpulkan data dari polis asuransi unit link dari tiga perusahan asuransi yang merupakan sampel dari penelitian ini.

2. Menyusun tabel perhitungan berdasarkan Tabel Mortalita 2012. Nilai yang akan dihitung adalah $q_{x}$ dan ${ }_{k} p_{x}$

3. Menghitung besar premi pertanggungan (baca: biaya asuransi unit link) dengan bantuan tabel perhitungan dengan terlebih dahulu menghitung nilai tunai anuitas dan uang pertanggungan.

4. Menghitung biaya, keuntungan (profit) dan return dari produk unit link. Pada langkah ini mula-mula akan dibangkitkan bilangan acak normal $(0,1)$ dan dihitung rataan dan standar deviasi dari historis return dari sampel. Setelah itu akan dilakukan perhitungan profit testing dengan menggunakan model stokastik untuk peserta berusia 25,35,45, dan 55 tahun. Pengolahan datanya dilakukan dengan menggunakan software Microsoft excel .

5. Menganalisis biaya asuransi, premi, keuntungan dan returnnya. Hasil perhitungan biaya asuransi pada langkah 3 akan dibandingkan dengan biaya asuransi yang tercantum pada polis dari sampel penelitian . Kemudian akan dianalisis premi, keuntungan, dan return dari 3 perusahan asuransi yang merupakan sampel dari penelitian ini.

\section{HASIL DAN PEMBAHASAN}

\subsection{Data Polis}

Pada bagian ini akan ditampilkan ringkasan ilustrasi (baca:data polis) dari Perusahan X, Y, dan Z.

- Perusahan Asuransi X menawarkan total manfaat meninggal sebesar $R p 21.000 .000,00$ ditambah nilai investasinya. Masa pertanggungan sampai usia 75 tahun. Adapun rincian biayanya adalah sebagai berikut: biaya administrasi Rp25.000,00/bulan, biaya asuransinya tahun ke-1 adalah $R p 42.210,00$, biaya pengelolaan dana maksimal $2 \%$ dari dana investasi yang dikelola. Besar preminya adalah Rp4.200.000,00 per tahun selama 5 tahun. Dari premi ini porsi untuk invesatsinya pada tahun pertama, kedua, ketiga, keempat, dan kelima berturut-turut adalah sebagai berikut: 40\%, 75\%, 90\%, 95\%, dan 95\%.

- Perusahan Asuransi Y menawarkan asuransi unit link dengan Uang pertanggungan Rp380.000.000,00. Sedangkan biaya asuransi bulanan dikenakan adalah Rp72.200,00. Besar biaya administrasi setiap bulannya Rp27.500,00 dan biaya pengelolaan setiap tahunnya $2 \%$ yang dibayarkan selama berlakunya asuransi. Premi berkala dibayarkan sebesar Rp4.000.000,00 per tahun selama 15 tahun. Dari dana premi ini, porsi untuk investasi pada tahun pertama, kedua, ketiga, keempat, kelima, keenam dan seterusnya berturut-turut adalah sebagai berikut: 0\%, $40 \%, 85 \%, 85 \%, 85 \%$, dan $100 \%$. Masa Pembayaran biaya asuransi dan administrasi (tidak lebih) 65 tahun. Pertanggungan diberikan sampai usia 99 tahun dengan catatan tidak terjadi lapsed. Selain itu polis dijami akan tetap berlaku dalam 10 tahun sejak tanggal mulai berlaku.

- Perusahan Asuransi Z memberikan Uang pertanggungan (nilai pertanggungan) sebesar Rp1000.000.000,00. Adapun biaya asuransi bulanannya adalah Rp178.400,00, biaya administrasinya Rp30.000,00, dan biaya pengelolaan $2,5 \%$ setiap tahun. Besar preminya dengan masa pembayaran selama 64 
tahun adalah Rp7.272.700,00 dengan porsi untuk investasi ada tahun pertama, kedua, ketiga, keempat, kelima, keenam dan seterusnya berturut-turut adalah sebagai berikut: $0 \%, 45 \%, 90 \%, 90 \%, 90 \%$, dan $102 \%$.

Selain itu pertanggungan akan tetap berlaku selama 8 tahun pertama polis meskipun nilai polis tidak cukup untuk membayar biaya-biaya yang ada.

\subsection{Premi Pertanggungan dari Produk Unit Link}

Pada bagian ini akan dihitung besar premi pertanggungan (baca: biaya asuransi unit link) dengan memanfaatkan data yang diperoleh pada bagian 3.1 dan persamaan (1) serta Tabel Mortalitas Indonesia. Untuk ilustrasi akan dihitung besar biaya asuransi dari perusahan $\mathrm{X}$ untuk usia 35 tahun dan suku bunga $6 \%$. Besar biaya asuransi tahun ke-1, untuk peserta yang berusia 35 tahun, adalah Rp42.210,00. Sedangkan, menurut Tabel Mortalitas Indonesia (TMI) peluang seseorang yang berusia 35 tahun akan meninggal sebelum mencapai usia 36 tahun adalah 0,001457 . Sehingga untuk mendapatkan uang pertanggungan sebesar Rp21.000.000,00 peserta asuransi harus membayar biaya asuransi sebesar $21.000 .000 * 0.001457 / 1.06^{0.5}$

$=29.721,29$ rupiah (dengan asumsi suku bunga $6 \%$ per tahun). Untuk perusahan $\mathrm{Y}, \mathrm{Z}$ dan umur $25,35,45$ dan 55 tahun dapat dihitung dengan jalan yang serupa.

Hasil selengkapnya dapat dilihat pada Tabel 1 dan Gambar 1

Tabel 1. Biaya Asuransi

\begin{tabular}{|l|l|l|l|}
\hline & $\begin{array}{l}\text { Uang } \\
\text { Pertanggung } \\
\text { an }\end{array}$ & $\begin{array}{l}\text { Biaya } \\
\text { Asuransi yang } \\
\text { ditawarkan }\end{array}$ & $\begin{array}{l}\text { Biaya } \\
\text { Asuransi } \\
\text { TMI }\end{array}$ \\
\hline $\mathrm{X}$ & 21.000 .0000 & 42.210 & 29.721 \\
\hline $\mathrm{Y}$ & 380.000 .000 & 866.400 & 537.814 \\
\hline $\mathrm{Z}$ & $\begin{array}{l}1.000 .000 .0 \\
00\end{array}$ & 2.140 .800 & 1.415 .299 \\
\hline
\end{tabular}

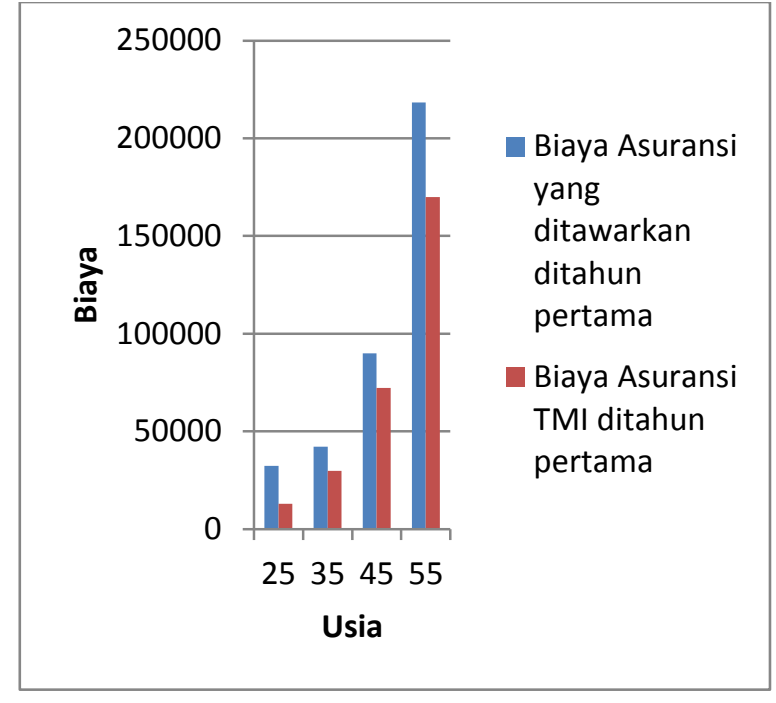

Gambar 1. Biaya Asuransi Perusahan $X$ untuk Usia 25, 35, dan 45 tahun

\subsection{Profit Testing}

Pada bagian sebelumnya telah dihitung besar biaya asuransi (mortality cost) dari perusahan unit link yang merupkan sampel dari penelitian ini. Pada bagian ini akan dihitung expected present value of future profit atau biasa disebut net present value (NPV). Untuk itu mula-mula akan dihitung profit emerging nya dengan menggunakan model stochastic yang mengasumsikan returnnya mempunyai distribusi lognormal.

Berdasarkan ilustrasi kontrak unit link diperoleh Tabel 2 berikut.

Tabel 2. Kinerja Unit Link

\begin{tabular}{|c|c|c|c|}
\hline \multirow{2}{*}{ Tahun } & $\begin{array}{c}\text { Hasil } \\
\text { Kinerja } \\
\mathrm{X}\end{array}$ & $\begin{array}{c}\text { Hasil } \\
\text { Investasi(\%) } \\
\mathrm{Y}\end{array}$ & $\begin{array}{c}\text { Hasil } \\
\text { Kinerja(\%) } \\
\mathrm{Z}^{*}\end{array}$ \\
\hline 2012 & 2464.71 & 8.82 & 11 \\
\hline 2013 & 2552.27 & -8.22 & 0.85 \\
\hline 2014 & 2927.99 & 14.51 & 22.33 \\
\hline 2015 & 2568.08 & -4.37 & -13.24 \\
\hline 2016 & 2800.45 & 9.39 & 12.91 \\
\hline
\end{tabular}

*Untuk perusahan Z kinerjanya 24.39(2010), 1.13(2011), 3.49(2017).

Dari Kinerja unit link, Tabel 2, diperoleh $\hat{\mu}_{X}=0.0319, \hat{\mu}_{Y}=0.04, \hat{\mu}_{Z}=0.07019 \quad$ dan $\hat{\sigma}_{X}=0.1165, \hat{\sigma}_{Y}=0.172, \hat{\sigma}_{Z}=0.1176$. 
Selanjutnya, nilai simulasi dari return yang mempunyai distribusi lognormal diperoleh dari hubungan berikut

$$
r_{t}=e^{\mu+\sigma z_{t}}
$$

dengan $z_{t}$ nilai yang disumulasikan dari distribusi $N(0,1)$.

$E[N P V]$ dengan jumlah simulasi, $N=1000$ dan tingkat kepercayaan 95\% disajikan pada Tabel 3 .

Tabel 3. Ekspektasi Net Present Value

\begin{tabular}{|c|c|}
\hline Perusahan & E $[N P V]$ (Rupiah) \\
\hline$X$ & $(3.504 .075,3.711 .248)$ \\
\hline$Y$ & $(3.749 .515,4.067 .178)$ \\
\hline$Z$ & $(1.784 .371,1.841,127)$ \\
\hline
\end{tabular}

\subsection{Analisis Hasil Penelitian}

Mula-mula akan dilakukan analisis terhadap biaya asuransi yang dibebankan oleh perusahan X, Y, dan Z. Dari Tabel 1 terlihat bahwa biaya asuransi yang ditawarkan dari ketiga perusahan asuransi tersebut masing-masing lebih besar dari biaya asuransi yang dihitung menggunakan Tabel Mortalitas Indonesia 2012 (TMI). Selanjutnya untuk uang pertanggungan yang sama, misalnya 1 unit, diperoleh biaya asuransi untuk perusahan asuransi $\mathrm{X}$, Y, dan $\mathrm{Z}$ berturutturut adalah sebagai berikut 0.002010, 0.0022800 , dan 0.002141. Ini berarti

\section{biaya asuransi $Y>$ biaya asuransi $Z$ $>$ biaya asuransi $X$}

Selanjutnya akan dianalis premi untuk perusahan X, Y, dan Z. Khususnya akan diselidiki apakah premi yang dibayarkan cukup untuk melunasi biaya yang meliputi biaya administrasi, biaya akuisisi, biaya asuransi dan biaya pengelolaan investasi. Untuk itu perhatikan hal berikut:

Dari ilustrasi manfaat perusahan $\mathrm{X}$ terlihat bahwa untuk dua tahun pertama nilai investasi (dalam ribuan rupiah) adalah sebagai berikut: 1.418, 4477 Bila dianalisis, untuk tingkat bunga $i_{t}^{f}=6 \%$, nilai ini ternyata diperoleh dengan menggunakan hubungan :

$$
F_{t}=\left(A P_{t}+F_{t-1}-B A S_{t}-B A D\right)\left(1+i_{t}^{f}\right)
$$

\section{Dengan}

$B A S_{t}$ adalah biaya asuransi (mortality cost) yg besarnya sesuai dengan usia

$B A D$ menyatakan biaya administrasi sebesar Rp300.000,00

Untuk ilustrasi, perhatikan perhitungan berikut

$F_{1}=\left(A P_{1}+F_{0}-B A S_{1}-B A D\right)\left(1+i_{t}^{f}\right)=0.4 \times$

$4.200 .000+0-42210-300.000=1418057$

$F_{2}=\left(A P_{2}+F_{1}-B A S_{2}-B A D\right)\left(1+i_{t}^{f}\right)=0.75 \times$

$4.200 .000+1418057-42210-300.000=$ 4477172 .

Perlu dicatat bahwa nilai investasi yang dimunculkan dalam proposalnya dihitung dengan biaya pengelolaan dana sebesar $0 \%$ (dalam brosur dari perusahan $\mathrm{X}$ dicantumkan biaya pengelolaan dana maksimal $2 \%$ ). Atau dengan kata lain, dalam contoh proposal (brosur), perhitungan ilustrasi manfaat perusahan $\mathrm{X}$ tidak/belum memperhitungkan biaya pengelolaan dana investasi. Selain itu, dari hasil analisis yang dilakukan pada perusahan $\mathrm{X}$ diperoleh terlihat bahwa premi yang dibayarkan paling lama selama 5 tahun cukup untuk membayarkan biaya manajemen dan biaya pengelolaan sampai dengan usia 75 tahun

Berbeda dengan perusahan $X$, untuk tahun pertama perusahan $\mathrm{Y}$ tidak memotong biaya asuransi dan administrasi. Maka biaya tersebut dinyatakan sebagai biaya terhutang. Untuk tahun berikut perhitungannya serupa dengan perusahan Z. Untuk ilustrasi, perhatikan perhitungan berikut

$F_{11}=\left(A P_{11}+F_{10}-B A S_{11}-B A D\right)\left(1+i_{t}^{f}\right)=$ $(5900.000+47038000-1501005-$ $330.000) 1.05=53662344$

Sama seperti perusahan $X$, perhitungan tersebut belum dipotong biaya pengelolaan dana. Selanjutnya, misalkan tingkat hasil investasi 5\% dan dana pengelolaan investasi maksiamal $2 \%$. Maka hasil perhitungan yang telah dilakukan menunjukkan bahwa dana premi yang dibayarkan selama 15 tahun tidak akan cukup untuk melunasi biaya asuransi dan biaya administrasi yang masa pembayarannya (tidak lebih dari) 65 tahun. Ini berarti polis tidak akan berlaku, kecuali peserta melakukan top-up. 
Selanjutnya, untuk perusahan $\mathrm{Z}$ untuk tahun pertama tidak ada dana yang tersisa untuk investasi. Dengan kata lain semua dana polis tahun pertama terserap untuk biaya. Dari hasil analisis diperoleh bahwa selama 8 tahun pertama terdapat lebih dari cukup dana untuk membayarkan uang pertanggungan. Tetapi selama beberapa tahun terakhir terlihat bahwa premi yang dibayarkan tidak akan cukup untuk membayarkan biaya-biaya yang timbul. Ini berarti kontrak polis batal kecuali perserta melakukan top-up.

\section{KESIMPULAN \& SARAN}

Hasil Simpulan yang dapat diambil sejauh ini adalah:

Biaya asuransi (mortality cost) yang ditawarkan oleh tiga perusahan unit link yang dipilih sebagai sampel penelitian ini lebih besar daripada biaya asuransi yang dihitung berdasarkan Tabel Mortalitas Indonesia.

Satu dari tiga perusahan asuransi unit yang diteliti, preminya cukup untuk mendanai jaminan.. Sehingga polis akan tetap berlaku sampai masa pertanggungan. Sedangkan yang lainnya harus melakukan Top-Up.

Pada penelitian ini manfaat proteksi yang dibahas hanya proteksi jiwa yang membayarkan uang pertanggungan jika peserta meningggal dunia. Untuk penelitian selanjutnya, proteksinya bisa diperluas. Misalnya proteksi jiwa dan kesehatan.

\section{DAFTAR PUSTAKA}

Bowers NL, Gerber H.U., Hickman, J.C., Jones, D.A., dan Nesbitt, C.J. 1997. Actuarial Mathematics. Schaumburg (DE): The Society of Actuaries. Terjemahan dari; Seimei Hoken Sugaku, Jokan (" 92 Revision).

Dickson, D.C.M., Hardy, M.R. \& Waters, H.R., 2009. Actuarial Mathematics for Life Contingent Risk. New York: Cambridge University Press.

Mandal, Satrajit. 2016. Unit linked Insurance Plans and Their Applications in India. Thesis. Tartu.

Soedibjo, S. Fitriati, R. 2009. Penetapan Target Premi Asuransi Jiwa Syariah untuk Mencapai Titik Impas dengan Pendekatan Model Profit testing. Bisnis \& Birokrasi, Jurnal Ilmu Administrasi dan Organisasi Vol.16, No.2, 56-67. 